\title{
COMMODIFICATION SEPARATED US \\ FROM NATURE, FROM EACH OTHER \\ AND FROM OURSELVES. CAN TECHNOLOGY \\ BRING US BACK TOGETHER?
}

\author{
SARA LUMBRERAS \\ Institute for Research in Technology, \\ Universidad Pontificia Comillas, Madrid
}

\begin{abstract}
Commodification is «the transformation of goods, services, ideas and people into standardized objects of trade». The establishment of an unsustainable economic system has long been linked to the commodification of nature. This paper presents a view of commodification as a process that has applied to a growing spectrum of human affairs, which includes not only nature, goods and labor, but also our body, experiences and relationships. The enabling role of technoscience is discussed.

The road to reconciliation - with nature, each other and ourselves - needs to recognize and appreciate what is unique and irreplaceable. This paper concludes with some possible roads for the use of technology as a tool for this reconciliation. Reversing this process if essential if we wish to establish a sustainable economy and a more human society.
\end{abstract}

KEY WORDS: commodification; ecology; technoscience; social media.

\section{La mercantilización nos separó de la naturaleza, del otro y de nosotros mismos. ¿Puede la tecnología volver a conectarnos?}

RESUMEN: La mercantilización se define como «la transformación de los bienes, servicios, ideas y personas en objetos de comercio estandarizados». Este artículo presenta una visión de la mercantilización como un proceso que se aplica no sólo a la naturaleza sino también a los bienes, al trabajo, al propio cuerpo, las experiencias y las relaciones. El artículo reflexiona sobre papel clave de la tecnociencia.

EL camino hacia la reconciliación - con la naturaleza, con el otro y con nosotros mismos - pasa por reconocer y apreciar lo que en ellos es único e irremplazable. El artículo concluye con algunas ideas iniciales sobre cómo la tecnología puede utilizarse como una herramienta. Dar marcha atrás en el proceso de mercantilización es esencial si deseamos establecer una economía sostenible y una sociedad más humana.

PALABRAS CLAVE: mercantilización; ecología; tecnociencia; redes sociales.

\section{COMmOdificATION}

Commodification is "the transformation of goods, services, ideas and people into standardized objects of trade». A commodity is, according to Appadurai, «anything intended for exchange,» or «any object of economic value» [1]. The process by which something — or someone- becomes a commodity is known as commodification ${ }^{1}$

1 Este artículo se vincula con el Proyecto de investigación: «La condición humana ante los retos de la Ecología» de la Cátedra Francisco José Ayala de Ciencia, Tecnología y Religión de la Universidad Pontificia Comillas. 
In the international markets, the term commodity refers to the material goods that are exchanged in the markets. Soft commodities are grown, such as cotton or cocoa. Hard commodities are mined, such as iron or zinc. Energy commodities include coal, oil or power. The fundamentals of commodities from a trading perspective are clearly presented in practitioner guides such as [2].

Present-day discussions of commodification tend to focus on services and industries where standardization results in shrinking profit margins. However, instead of focusing on margins, I would like to focus on the following points as defining commodification:

- First and foremost: in commodities, standardization removes all possible differentiation or, alternatively, renders it irrelevant. Any qualities or declinations of the commodity that are considered important are set into sub-standards known as grades. Grades should be objectively defined and externally assessable.

- They are strictly interchangeable. One oz of $24 \mathrm{k}$ gold is strictly as valuable as another. They can be substituted.

- In addition, the value of two units of a commodity is strictly the samethey can be exchanged in the markets. For this, it is necessary that these markets are liquid; that is, it should be sufficiently easy and quick to find a buyer or a seller.

- Given that commodities can be easily exchanged in the markets, it makes economic sense to accumulate them. Any surplus can be exchanged for money. It should be noted that, when a good cannot be exchanged in a liquid market, accumulating it above one's needs does not necessarily increase utility.

Commodification has occurred in an increasingly wider context, in a process that has been unfolding over centuries. This paper describes the main forms where commodification has taken place. All these forms are related and have blurred edges. I will start by reviewing the commodification of nature that has played a major role in the development of our unsustainable economic system. Then, I will move on to the objectification of goods, labor, our own body, experience and relationships. The role of technology as an enabler of the process of commodification will also be discussed. Finally, I will present some ideas on how reversing this process is an essential step if we wish to establish a sustainable economy and a more human society and how technology could be of use.

\section{The COMmOdification OF NATURE}

Capitalism has long been understood as a belief system [3] or as a religion of sorts [4]. It seems clear that in the capitalist worldview, nature is a commodity, which becomes a mere input factor for production. However, some authors 
have argued that the commodification of nature did not start with industrial production but much earlier than that [5].

The economic system of the West was not always unsustainable. Medieval farming practices included crop rotation, where an established series of different crops (a cycle) is grown in the same area in sequenced seasons so that the soil is not constantly used for one set of nutrients. Fallow allowed the land to rest between harvests. This structure was indeed sustainable in origin - or very close to-. However, the move to cities in the Modern Period started a disconnection between people and the limitations of the land. Imperialism further intensified this trend: land appears as a resource that can be used, spent and wasted.

I would like to argue that these changes did not completely crystallize until well past the middle of the XXth century. For instance, my own father lived his childhood and the first years of his youth in a small village in the plains of Castilla. The whole village worked either the land (which was good for wheat, barley and a very priced local variety of chickpea) or fed cattle. Until the mid fifties, he had seen little to no automation of the land labor. They reaped by hand exhaustingly under the summer sun. Horses and mules were used for plowing and other field labor, donkeys were used for transportation. Crop rotation was strictly followed. Cattle were fed on what remained on the land after the harvest, and returned the manure to the ground as a natural fertilizer. The first change, preceding the first tractor, was the import of fertilizer, in particular, nitrates coming from Chile or Norway. This development meant that crop rotation and fallow were abandoned. One or even two harvests per year were possible. Shortly after that, the mechanization of agrarian labor lead to a massive rural exodus to the cities: most of the population, who had been laboring the same lands for generations, was now completely detached from them and ancestral knowledge was lost. My father's generation knows everything about the cycles of seeding and reaping; I could barely tell the difference between barley and wheat. The land is now just a resource that is used as an input in the production of crops, in the same way that raw materials were used as an input in industrial production.

It is difficult to overstress the role of technology in this process: fertilizer and other intensive-agriculture practices were instrumental in pushing the limitations of the land. They made it possible to reverse the damage inflicted and restore and improve yields. As an illuminating example: in medieval times, only cattle manure was used as fertilizer. Ironically, manure is the single worst source of water pollution globally. Nowadays, it is not even worth using it as a fertilizer.

In addition, the development of quick and cheap transportation enabled the long-distance trade of crops. It should be noted that the New York Stock Exchange appeared at the same time that the trade of wheat and corn developed thanks to the newly created railways. 
2. IDEAS BEFORE FACTS: AN OBJECTIFYING WORLDVIEW?

Richard Tarnas [6] argues that commodification —or, in his words, the objectification process - was an epistemological one. He explains that the primal worldview, the original way in which our Western society understood the world (as well as many other cultures), presented a universe that was filled with meaning and spirit. Land, animals, all the workings of nature, the cycles of seasons and the movements of the stars. The self was part of a bigger universe which was endowed with the same attributes as human beings.

The start of the Modern Period coincided with a paradigm shift. The modern worldview separated subject and object. Human beings were the sole subjects, owners of intentionality and custodians and creators of meaning. Nature came to be understood as an object, without meaning in itself, without intentions of its own. The rules of nature - blind and objective- could then be studied and, with this idea, Modern Science was born.

This worldview shift took place, according to Tarnas, in the years surrounding the Copernican Revolution (which coincides nicely with the increase of population in cities and with Imperialism). Modern Science set in motion the processes that emancipated human beings from the rules of nature, and which present-day technoscience is still developing. The price to pay for this was, again in Tarnas' words, to live in a disenchanted universe. This conversion was not only at the root of the Scientific Revolution, but also grounds the current trends supporting atheism and secularization.

In this paper, I would like to interpret this paradigm shift as an ongoing process rather than a single event. A process that affects an increasingly wide scope and that results in the objectification of a growing sphere of reality.

\section{The COMmOdification OF GOODS}

Again, the growth of cities and the improvements in transportation made possible the creation of a money economy. Previously, barter used to account for most of the exchanges, so they were not as frequent. This, in itself, commodified to some extent the products of agriculture: they could be bought and sold easily and in a timely manner. However, crafts (such as pottery or clothing) took longer to undertake this process; until the Industrial Revolution. Marx [7] links commodities to industrial production, defining commodities as «those goods produced under the alienating conditions of capitalist labor». Indeed, the Industrial Revolution radically changed the way crafts were produced. In medieval times, guilds scrupulously controlled production as well as the conditions for labor. Quality was zealously ensured by the craftsman, as his honor depended on it - and he could be expelled from the guild if a serious mistake was made. Manual production meant as well that any good could be easily customized to suit its user. 
All this changed in the Industrial Revolution. Division of Labor meant that, although production processes were now much more efficient, no single worker felt responsible for the product, being alienated from it in Marx's terms. We could understand that it is not only the man producing the good, but also the one buying it, who are alienated from the product. For the later, the good has not been manufactured directly for him. It is only his because he owns it, but the object did not have him as its purpose and cannot be distinguished from a similar object. It is important to note that in the Industrial Revolution, customization practically disappeared. As the car manufacturer Ford famously announced: «Clients can have their car any color they want, as long as it is black». The possibility of customizing the objects of production only re-emerged at the very end of the XXth century thanks to smart automation and mass-customization tools.

In addition, quality standards severely suffered given that no specific worker was responsible for the product. Indeed, there was not even a concept for quality manager until almost two centuries after the Industrial Revolution. We could argue that quality standards only recovered with the development of Statistical Quality Control tools after the Second World War, a true milestone for Engineering ${ }^{2}$. This fact, together with the ubiquitous programmed obsolescence, where goods are manufactured to have an intentionally short lifespan, and the establishment of quick fashions, meant that replacing items was necessary more often than it used to. Furthermore, professionalization meant that less and less people were able to make their own repairs. Finally, the decreases in prices meant that the replacement was affordable, so that repairs were not attractive from a purely economic standpoint - and, therefore, making a life out of repairing professionally was not attractive either. This meant that using and wasting became the new norm.

In this setting, there is nothing of the character of the user in the object. Nothing distinguishes one object from another, they are interchangeable and subject to accumulation. In addition, the lack of customization has interesting implications in the emergence of fashion: if a product is personalized, it should not be subject to such quick variations in taste. In addition, the fast cycles of replacement make it more difficult to develop any connection with our material belongings; it is more difficult to get attached to them and more difficult to fully enjoy the experience of using them. The object is commodified, it is disenchanted. That is probably one of the reasons why, in a consumerist society, the focus is given to buying rather than using, with compulsive shopping emerging as a widespread epidemic.

2 After the Second World War, the US wished to establish commercial relations with Japan among other countries. For this, they created alliances based on outsourcing production. However, the percentage of defective items that were produced was too high to be considered worthwhile. Infamously, in one radio-production factory, the ratio of defective items was over $50 \%$. In order to fix this, the US sent their most knowledgeable quality engineers to Japan. The Japanese did indeed learn their lessons - and took the field to the next level, making Japan an international reference in this context [23]. 


\section{THE COMMODIFICATION OF LABOR}

Industrial production and in particular the division of work and wage labor meant that workers were now treated as a commodity. The assembly-line worker was far removed from the proud craftsman; his training to perform his duties was minimal and had a purely mechanical input in the production process. Workers were made equal with respect to the production process, interchangeable, tradable: commodified.

The case of care work as opposed to production is especially interesting [8], as it is commonly understood that it is supported on loving relationships. Placing this in a wage setting could be problematic - because it is not entirely commodifiable. The overwhelming majority of this type of work does not receive a wage and is thus invisible to the market. The immediate consequence of this is its invisibility. As some have denounced, this results in a lack of basic material security for those who perform this work, which is mostly women [9].

When a process is commodified, it is only valued by its outcome. Hence, different workers that can achieve the same output are valued equally. It is difficult to establish objectively the output of care work, and this might also be a factor at play in this issue.

On a related note, while non-qualified work can be assessed straightforwardly in terms of raw output (for instance, parts produced), this was not as easy to undertake in qualified jobs. However, the current job market tends to focus increasingly more on quantifiable outcomes, for instance highlighting completed projects over past positions. This could be understood as a commodification of experience. The accumulation of completed projects in a $\mathrm{CV}$ makes it possible to compare different job candidates in quantifiable terms. Globalization supports this trend by opening the job market to an increasingly number of candidates - that is, the job market is getting more and more liquid, which further helps the commodification process.

The commodification of work leads to accumulation, either in the form of raw production output for unqualified labor or completed projects for qualified workers. This tendency for accumulation, understood as a process that increases not only the wealth of the individual but also his social worth, is behind our characterization as an overworked, burnout society [10].

\section{THE COMMODIFICATION OF THE BODY}

The commodification of labor is also linked to the commodification to the body. In English, workers have long been referred to as «hands» [11]. The most extreme example of commodification of the body is slavery. Dehumanization by objectification is intrinsic to enslavement (Patterson 1982). Current forms of slavery include domestic service and child labor, as well as sexual exploitation and the often-related human trafficking. 
Lesley Sharp has studied the issue of commodification of the body extensively [12]. Again, in this context, women historically have been (and continue to be) especially vulnerable. The female body is often valued for its reproductive potential separate from their consideration as human beings. Women's bodies are, as explained by Sharp, "fragmented in a host of ways, so they are reduced to vaginas, wombs or breasts». The key examples of these practices would be prostitution, surrogate pregnancy and wet-nursing (where a woman breastfeeds another woman's baby in exchange for a wage and often at the expense of her own children [13]).

Plastic surgery is another example of commodification of the body that has been on the rise the last decades. Elective forms of body transformation to comply with aesthetic norms anchor the social worth of human beings on an objectified view of their bodies [14], and make body parts susceptible to be traded. The issue of body enhancement and cyborgs can only exacerbate this trend.

The role of medicine is obvious in the previous examples. Reproductive techniques are necessary for surrogate pregnancy; the evolution and costdecrease of new surgery techniques was necessary for the growth in plastic procedures.

\section{THE COMMODIFICATION OF EXPERIENCE}

As in the commodification of work, when an experience has been commodified, its only important aspect is its outcome. It can be replaced, traded, and the desirability to accumulate it appears.

Mauss pointed that the language of gift exchange may obscure capitalist forms of commodification [15]. In our context, it is important to note that two forms of commodification might be concurring at the same time. For instance, in prostitution, the objectification of the woman's body happens at the same time that the experience of sex is commodified itself.

Information and Communication Technologies and, in particular, social media, make it very easy to share the superficiality of experiences. We are now used to seeing images of people taking photos or videos, getting distracted from enjoying their own experiences. Many travel, at least in part, for the sake of pictures: "pics or it didn't happen». Food can be more valued for their aesthetics than for their taste. The possibility of taking better self-portraits or selfies is shaping the cellphone industry. As in the other targets involved, commodification leads to accumulation: more pictures, more trips, more tasty meals. Accumulation, in turn, enhances the devaluation of experience.

Valuing the experience only by its commodified outcome steals it from its very essence: the nature of the experience belongs to the subjective sphere, which is rendered irrelevant in the current context. The most fragrant example of this is pregnancy and childbirth, which have traditionally been recognized 
as deeply spiritual [16]. Most medical contexts value childbirth only by its final product: hopefully, a healthy child. This justifies an increasingly medicated process, which not only hinders the intensity of the experience but in many cases even threatens its safety [17]. As remarked in some recent studies [18], the complaints of women that have suffered a negative experience during childbirth tend to be taken as unimportant if their baby is healthy. As a midwife puts it: "If a bride gets seriously ill on her wedding day and the marriage ceremony ended up being performed quickly by the operating table, people would sure not tell her to be happy, because she has a wonderful husband and is married after all». Childbirth is arguably a much more important experience than a wedding ceremony, yet its significance is socially downplayed. The most extreme example of the minimization of the significance of pregnancy and childbirth is surrogate pregnancy, in which the commodification of experience converges with the ultimate form of objectification: the one of a human being.

\section{THE COMMODIFICATION OF RELATIONSHIPS}

Urbanization had interesting consequences on the nature of relationships. One of them was that it became possible to always (or almost always) meet new people, without needing to travel. It is easy to imagine that this had a damaging effect on the stability of relationships.

More recently, one of the first impacts of social media was to make relationships «countable». It has long been theorized that a human being cannot keep more than around 150 meaningful relationships (the Dunbar's number [19]). However, social network sizes can easily exceed one thousand [19], [20]. Thanks to ICTs, the accumulation principle also applies to friendship or to professional connections. In addition, more means of quantification emerge in social media, in the form of likes, followers or endorsements. This accumulation can result in obsessive behavior, which has been documented for some time as cellphone addition [21].

Some authors have started theorizing the impact of social media on the dating landscape. Dating apps show potential partners in a catalogue of sorts. The process of commodification displays the same characteristics as described in the first sections of this paper, such as the emergence of grades (some dates are more desirable than others, based on easily assessable factors than in this case tend to reduce to physical features) and a tendency for accumulation. The accumulation operates in the space of dates with different people, so that dating twice the same person is valued less than dating two different people. This effect makes it increasingly challenging to connect with at a deeper level, making it difficult to start true relationships. A recent article compares dating apps to a marketplace for love [22], which would have the peculiarity of making us lonelier than ever. 
CONCLUSIONS. REVERSING THE COMMODIFICATION PROCESS FOR

A SUSTAINABLE ECONOMY AND A MORE HUMAN SOCIETY

Technology played an enabling role in the commodification process that separates us from nature, from our work, body and experiences and finally isolates us from each other. Fertilizer made it possible to stretch yields past the original capacity of the land and abandon the once-sustainable farming practices of crop rotation and fallow. Improvements in transportation enabled the creation of wider market exchanges, which commodified food production. The development of the Industrial Revolution commodified produced goods and labor. Modern medicine, which had remarkable success in increasing our life expectancy and quality of life, had also the negative effect of commodifying our bodies. Finally, ICTs and in particular social media have resulted in an ongoing process of commodification of experience and relationships.

As discussed above, the start of the process of commodification coincided in time with the advent of the modern scientific paradigm, which is anchored in a worldview that separates subject (the human being who observes) from object (the nature that can be known). This process has progressively encompassed a wider context, separating us from nature, from each other, and from ourselves.

How would it be possible to stop and reverse the commodification process? The road to reconciliation - with nature, each other and ourselves- needs to recognize and appreciate what is unique and irreplaceable in everyone and everything. Although technoscience enabled the process in the first place, it can also facilitate its reversal. Some starting ideas are discussed below.

Technology can help to put us in contact with the characteristics of objects that are not measurable objectively, their history, their origins. This might be implemented as interactive labeling that, for added usefulness, could be linked to sustainability or social impact metrics (what is known as ESG: Environmental, Social, Governance metrics).

It is also necessary to strengthen the link between objects and their users. With mass customization, the Digital Revolution can restore some of what the Industrial Revolution took away. In addition, technologies such as 3D printing have the potential to democratize production. This will have added advantages such as making repairs easier, as the user is much more acquainted with the product and its workings.

As discussed above, the increase in customization would probably make fashions less relevant, as well as decreasing the attractiveness of accumulation. However, raising awareness of environmental problems would still be necessary to minimize the pervasiveness of the buy-use-waste cycle.

ICTs can create new marketplaces that enhance sustainability, such as second-hand websites. Markets should be designed carefully to serve the purposes of sustainability and humanization.

The subjective properties of experience should be stressed and valued. For this, a change of perspective in the sciences is needed. Although the subject- 
object dichotomy has given us Modern Science, it is time we reintroduce the value of subjectivity and authenticity - even if it is only for the sake of our happiness.

An awareness of these issues can maybe lead to changes in the design of social media or dating apps that minimizes their negative effects as much as possible while keeping their core usefulness. Social media could then be used to keep in touch with friends - rather than collect them.

Technoscience can help us revert the path that took us, from an enchanted universe where everything had a soul, to a world were even our fellow human beings are treated as commodities. The road to reconciliation -with nature, each other and ourselves- needs to recognize and appreciate what is unique and irreplaceable in each of us. Maybe we can use technology to enchant the universe again.

\section{REFERENCES}

[1] A. Appadurai (1988). The Social Life of Things: Commodities in Cultural Perspective. Cambridge: University Press.

[2] H. Geman (2005). "Commodities and commodity derivatives, M Modeling and Pricing for Agriculturals, Metals and Energy, Chichester (Grande-Bretagne): Wiley Finance.

[3] K. Tanner (2010). «Is Capitalism a Belief System?» Anglican Theological Review, vol. 92, (4), pp. 617.

[4] H. Cox (1999). «The market as God: Living in the new dispensation,» The Atlantic Monthly, vol. 283, (3), pp. 18-23.

[5] M. S. Northcott (1996). The Environment and Christian Ethics. Cambridge: University Press.

[6] R. Tarnas (1996). The Passion of the Western Mind: Understanding the Ideas that have Shaped our World View. Random House, 218.

[7] K. Marx (1965). Capital: A Critical Analysis of Capitalistic Production. Progress Publishers, 3.

[8] S. Himmelweit (1999). "Caring labor,» Ann. Am. Acad. Pol. Soc. Sci., vol. 561, (1), pp. 27-38.

[9] K. Silbaugh (1997). «Commodification and Women's Household Labor,» Yale JL \& Feminism, vol. 9, pp. 81.

[10] B. Han (2015). The Burnout Society. Stanford: University Press.

[11] Dickens, C. (2016). Hard Times. Lerner: Publishing Group.

[12] L. A. Sharp (2000). The commodification of the body and its parts,Ç Annu. Rev. Anthropol., vol. 29, (1), pp. 287-328.

[13] S. B. Hrdy (1992). "Fitness tradeoffs in the history and evolution of delegated mothering with special reference to wet-nursing, abandonment, and infanticide,» Ethol. Sociobiol., vol. 13, (5-6), pp. 409-442.

[14] A. Balsamo (1992). On the Cutting Edge: Cosmetic Surgery and the Technological Production of the Gendered Body. na.

[15] M. Mauss (1967). «The Gift, trans. Ian Cunnison,» New York and London: WW.Norton \& Company, pp. 9.

[16] P. Van Cappellen et al (2016). «Effects of oxytocin administration on spirituality and 
emotional responses to meditation,» Social Cognitive and Affective Neuroscience, vol. 11, (10), pp. 1579-1587.

[17] B. Smulders, M. Croon and R. C. Feenstra (2002). Parto Seguro: Una Guía Completa. Médici.

[18] I. O. Fernández, D. R. Berdún and C. is Ours, «Midwives experiences regarding obstetric violence».

[19] R. Dunbar (2010). How Many Friends does One Person Need?: Dunbar's Number and Other Evolutionary Quirks. Faber \& Faber.

[20] D. McRaney and D. McRaney (2011). You are Not so Smart: Why You have Too Many Friends on Facebook, Why Your Memory is mostly Fiction, and 46 Other Ways You'Re Deluding Yourself. Gotham Books/Penguin Group.

[21] X. Carbonell et al(2009). "A bibliometric analysis of the scientific literature on Internet, video games, and cell phone addiction,» J. Med. Libr. Assoc., vol. 97, (2), pp. 102-107.

[22] H. Robinson (2018). «Tinder: The Marketplace for Love,» Critical Reflections: A Student Journal on Contemporary Sociological Issues, vol. 6.

[23] M. Walton (1988). The Deming Management Method: The Bestselling Classic for Quality Management! Penguin.

Institute for Research in Technology

SARA LUMBRERAS

Escuela de Ingeniería, ICAI,

Universidad Comillas, Madrid

sara.lumbreras@iit.comillas.edu

[Artículo aprobado para publicación en enero de 2019] 